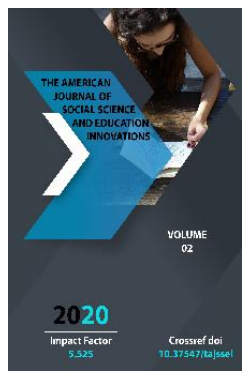

\title{
The Importance Of Historical And Artistic Works In Forming The Qualities Of Courage In Future Military Men
}

\author{
Murodillaeva Munavvarxon Usmanovna \\ Senior Teacher Of The Academy Of Armed Forces Of The Republic Uzbekistan, Tashkent, \\ Uzbekistan
}

Journal Website:

http://usajournalshub.c

om/index,php/tajssei

Copyright: Original

content from this work

may be used under the

terms of the creative

commons attributes

4.0 licence.

\section{ABSTRACT}

In the historical development of personality, the creation of written sources, including historical and historical-artistic works, had a direct impact on the development of social relations. The educational influence of ideas put forward in such works has created an opportunity for centuries to use them in the formation of moral and moral qualities in a person. The reflection of individual-specific will qualities in the artistic image of historical heroes encouraged the younger generation to become courageous. The theme of military courage in historical and artistic works, which occupy a place in Uzbek and world literature, forms the basis of the plot. These works serve to develop the qualities of military courage of young people, especially, military men in modern conditions. This is what is mentioned in the article.

\section{KEYWORDS}

Historical-artistic source, historical hero, artistic hero, higher military educational institutions, courage, military courage, qualities of military courage, development of qualities of military men.

\section{INTRODUCTION}

Each stage of human society ensures that radical changes take place in the content of social relations. The changes that are taking place require the individual to adapt to them. Qualified professionals must have a sufficient understanding of the nature of the general changes taking place in society, be aware of the processes relevant to the field in which they operate. Therefore, the most important condition for the development of any industry 
is a market economy - the ability of the specialist to withstand it in the presence of strong competition.

One of the foundations of a country's political independence and national governance is the military. As in all spheres, the military system must be able to adapt to the ongoing socioeconomic and cultural changes in society, to operate in accordance with the requirements of the time and social needs. At the same time, it is necessary for specialists in the field to identify problems that ensure the future development of the system, identify measures to find solutions, the correct organization of the measures. The Law of the Republic of Uzbekistan "On General Military Obligation and Military Service" in the training of military personnel, the Law of the Republic of Uzbekistan "On Defense Doctrine" of January 9, 2018.

The ongoing trends of globalization, professional mobilization, information security at the international level require the promising development of the Armed Forces of Uzbekistan under certain conditions. Improving the mechanisms of professional development of future officers in higher military education, modernization of the military education system, introduction of state educational standards based on advanced innovative approaches, introduction of the most advanced pedagogical technologies in the educational process, providing the Armed Forces with modern military equipment; reliance on international experience and national values in the development of the system ;various stages ("Temurbek School", junior training center, higher military educational institutions Chirchik Higher Tank Command-Engineering School, Application of innovative technologies in the training of military personnel at the
Higher Military Aviation School of Uzbekistan, the Military Medical Faculty under the Tashkent Medical Academy, the Military Institute of Information and Communication Technologies and Communications, the Armed Forces Academy; formation of qualities of professional mobility (active implementation of modern educational principles and innovations in teaching practice, rapid adaptation to constantly changing educational conditions) in the teaching staff of military educational institutions; imposes conditions that must be met, such as the development of the professional competence of military personnel. Introduction of innovative technologies in the process of military training at the Armed Forces Academy; formation of qualities of professional mobility (active implementation of modern educational principles and innovations in teaching practice, rapid adaptation to constantly changing educational conditions) in the teaching staff of military educational institutions; imposes conditions that must be met, such as the development of the professional competence of military personnel. Introduction of innovative technologies in the process of military training at the Armed Forces Academy; formation of qualities of professional mobility (active implementation of modern educational principles and innovations in teaching practice, rapid adaptation to constantly changing educational conditions) in the teaching staff of military educational institutions; imposes conditions that must be met, such as the development of the professional competence of military personnel. 


\section{MATERIALS AND METHODS}

Its passage in the context of historical events [7] has been recognized as an important feature of historical and artistic works.

Significantly, "the best examples of historical and artistic works reflect not only aesthetic, but also knowledge that represents historical values" [11]. It is these historical values that serve to cultivate and develop the qualities of courage in cadets. Indeed, historical values are of universal importance to the peoples of the world. Universal historical values are, by their nature, divided into two groups - material and spiritual values. While historical and artistic works themselves are considered material values, the ideas and views expressed in them are intangible values that meet the spiritual and moral needs of the individual. Among the intangible universal values are the fight against any war, the protection of the security and peace of the country, the establishment of relations of tolerance, neighborliness and cooperation,

Courage is a nurtured trait of a character, through which a person overcomes his fears in order to achieve specific goals; walking forward, even in fear; not the absence of fear, but rather the overcoming of existing fear [8]; it is a personal quality that changes very little over time, and if a person is courageous in his youth, he develops courage as he grows older" $[16,262]$. In everyday life, courage is seen in the military, in emergencies, in sports, as well as in family upbringing [16].

M.N.Movchan notes that courage varies in nature. There are a number of material and spiritual factors that motivate a person to act boldly. These are moral obligation to other people, despair, personal interests, love, friendship, order, mutual support, justice, and so on [9]. The author notes that courage always requires willpower (volitional effort), and willpower, as is well known, always represents a conscious approach to a situation. Voluntary actions are not manifested in the situation when a person says "I want", "I need", but when he consciously sets a goal (s), and in this case, "I have to do" or "I have to do" [9]. Indeed, courage is a moral category that belongs to the will qualities.

In essence, courage varies. In particular, physical courage; intellectual courage, spiritual courage [8].

Defending the country, fighting the enemy, defeating him, as well as saving the lives of others is a shining example of physical courage, even if he risked his life by overcoming fear in wars, battlefields, as well as in emergencies.

Scientific courage represents a certain periodic effort to find proof of a particular hypothesis put forward, despite the existing difficulties, and to substantiate it with scientific evidence. Many of the discoveries made in human history are the result of hard work, many years of consistent effort. Even when a hypothesis is rejected by the scientific community, it is an expression of scientific courage not to give up one's views, to try to find a solution to a scientific, technical or technological problem. Among them are the courage of Nicolaus Copernicus, Jordan Bruno, Galileo Galilei.

V.Solovev emphasizes that the formation of the qualities of courage in a person is associated with the elimination of fear in him. The author considers fear to be a negative emotional experience and analyzes courage and bravery as the opposite qualities towards 
it. V. Solovev considers courage as a good quality that allows a person to defend himself, and its existence is a divine blessing, and its absence is considered a shameful state [14, 131].

Yu.V.Shcherbatyx believes that there must be a danger for the person to show heroism, courage. After all, it is impossible to plan in advance a situation that represents heroism, courage, and personal behavior. Moments of heroism and courage occur in a minute, when it is impossible to think, analyze, evaluate the consequences of a person's actions $[16,275]$ despair, hatred of the enemy also inspires courage. However, frustration, a loss of confidence in the future, for example, a person's abusive dissatisfaction with a system of governance that has been violated, is inherently negative in nature, even if it is the result of his or her courageous actions. Consequently, the action of the person whose rights have been violated to restore them is determined by legal norms. In this case, it is reasonable to apply to law enforcement agencies at several stages (instances) to restore the violated rights of the person.

\section{RESULTS}

Military courage is a quality inherent in a military specialist, which requires a high level of professional duties and responsibilities. Unlike other fields, a specialist working in the military field must be able to have the qualities of courage in accordance with the requirements of professional activity. Consequently, he is a direct participant in military processes such as guarding the borders of the Motherland, maintaining peace in the country, overcoming armed conflicts. Guarding the borders of the homeland, maintaining the peace of the country, and overcoming armed conflicts, of course, require courage from the military.

\section{CONCLUSION}

Development of qualities of military courage -

1) requiring a high level of professional duties and responsibilities in the future military specialist: fearlessness, courage, bravery, bravery, courage, bravery, perseverance, courage, perseverance, despair, courage, nobility, loyalty, courage the process of pedagogical activity aimed at developing the qualities of trust and a sense of honor;

2) not to be afraid, courage, bravery, bravery, courage, bravery, perseverance, courage, bravery, perseverance, despair, not shyness, nobility, loyalty, heroism, selfconfidence and dignity in accordance with the requirements of professional duties and responsibilities of a military specialist development process. In both cases, the organization of the process is carried out at the expense of solving organizational and methodological issues. Therefore, it is important to properly and rationally address organizational and methodological issues in these processes.

\section{REFERENCES}

1. Decree of the President of the Republic of Uzbekistan No. PF-4947 of February 7, 2017 "On the Strategy of Actions for the Further Development of the Republic of Uzbekistan" // Collection of Legislation of the Republic of Uzbekistan, 2017, No. 6, Article 70.

2. Resolution of the Cabinet of Ministers of the Republic of Uzbekistan dated February 23, 2018 No VM-140 "On approval of the Concept of educating youth in the spirit of military patriotism." 
3. Loyalty, valor, courage and honor - these qualities are not for show // http: // www.loevkraj.by/2014/02/.

4. Zhytomyr N. N. Historical and artistic book for children and its educational significance. - St. Petersburg: "Peter", 2005. - P. 76.

5. The meaning of "Historical novel"//https:// kartaslov.ru / meaning-words / historical+novel.

6. "Iliad" and "Odyssey" as a historical source // https: // studopedia.ru / 510190.

7. Historical novel //https://kartaslov.ru/kartaznaniy/ Historical + novel.

8. A final essay on the literature of 2018. Direction "Courage and cowardice" //https://docs.google.com/document/previe w.

9. Movchan M. N. Fear and courage in the dynamics of relationships. https://www.gramota.net/materials/3/2013/ 12-3/29.html.

10. Courage, bravery, and heroism are qualities that are ageless. //http://xn7sbfpkcabaodcvcjgaj5ug.xn-p1ai/sochineniya1/file/10494.

11. Features of the historical genre of fiction // http://www.edufacts.ru/lefabs-348-1.html.

12. Courage // https://ru.wikiquote.org/wiki/.

13. Courage, bravery, generosity and courage - the original qualities of the defender of the

Fatherland

//http://gumcollege.ru/news/smelost otvaga blagorodstvo i muzhestvo iskonnye kachestva zashhitnika otechestva/2018-0226-372.

14. Bravery, loyalty and bravery - high qualities //http://uza.uz/ru/society/ khrabrostpredannost-i-otvaga-vysokie-kachestva13.01.2012-17703.

15. What is bravery//http://www.xapaktep.net/virtues/ universal/ bravery / desc.php.
16. Shcherbatykh Yu. V. Psychology of fear: a popular encyclopedia. - Moscow: Eksmo, 2007. - P. 262.16. Shcherbatyx Yu. V. Psychology of straxa: a popular encyclopedia. - M.: Eksmo, 2007. - p. 262. 